\title{
ANALISIS PERTUMBUHAN TEKNOLOGI, PRODUK DOMESTIK BRUTO, DAN EKSPOR SEKTOR INDUSTRI KREATIF INDONESIA
}

\author{
Nandha Rizki Awalia ${ }^{1}$, Sri Mulatsih ${ }^{2}$, Dominicus Savio Priyarsono ${ }^{2}$ \\ ${ }^{1}$ Mahasiswa Magister Program Studi Ilmu Ekonomi, FEM IPB \\ ${ }^{2}$ Staf Pengajar FEM IPB
}

Artikel diterima Oktober 2013

Artikel disetujui untuk dipublikasikan Desember 2013

\begin{abstract}
Creative industries are seen to be important for the economic well-being, proponents suggesting that human creativity is the ultimate economic resource. This research seeks to explore the technology progress measured by total factor productivity (TFP) growth of creative industry in Indonesia, analyze how external factors influence GDP of creative industry (education, TFP growth, the number of companies, the number of labors, and government policy), and analyze the causality between GDP and export of creative industry using Granger Causality Test. This research uses panel data, representing pooled of time series data (year 2006-2013) and cross section data (14 subsectors of creative industry). The results shows that (1) TFP growth of 4 creative industry subsectors are negative: architecture, interactive games, computer programs, and research and development; (2) factors influencing the GDP of creative industry positively: education, TFP growth, the number of labors, and government policy; (3) there is two-way-causality between GDP and export of creative industry.
\end{abstract}

Keywords: creative industry, TFP, panel data, Granger causality.

\section{PENDAHULUAN}

\section{Latar Belakang}

Banyaknya penemuan baru di bidang teknologi informasi dan komunikasi telah menjadikan manusia semakin produktif dan pasar pun semakin luas. Hal ini menyebabkan persaingan antarmasyarakat menjadi semakin tinggi dan menuntut masyarakat untuk kreatif. Kreatifitas manusia sudah ada sejak lama, seperti seni, film, dan musik. Produk dari kreatifitas didominasi oleh jasa. Menurut Abraham (1984), permintaan terhadap jasa semakin tinggi, setelah seseorang mampu memenuhi kebutuhan dasarnya.
Oleh karena itu, dengan semakin tingginya pendapatan masyarakat, permintaan terhadap jasa akan meningkat. Meningkatnya permintaan terhadap jasa mendorong berkembangnya industri jasa, salah satunya adalah industri kreatif.

Menurut Kementerian Pariwisata dan Ekonomi Kreatif (Kemenparekraf) (2013), pesan besar yang ditawarkan ekonomi kreatif adalah pemanfaatan cadangan sumber daya yang bukan hanya terbarukan, bahkan tak terbatas, yaitu ide, talenta dan kreativitas. Dengan kata lain, ekonomi kreatif merupakan manifestasi yang sangat penting untuk mempertahankan perekonomian bagi 
negara-negara maju dan juga menawarkan peluang yang sama untuk negara-negara berkembang.

Industri kreatif memberikan kontribusi PDB hingga 7,02 persen pada tahun 2013. Berbagai subsektor dalam industri kreatif berpotensi untuk dikembangkan karena Bangsa Indonesia memiliki sumberdaya insani kreatif dan warisan budaya yang kaya. Selain memberikan kontribusi yang signifikan terhadap perekonomian nasional, industri kreatif juga mampu menyerap tenaga keja sebesar 10,65 persen dan menyumbang nilai ekspor sebesar 5,51 persen terhadap ekspor nasional pada tahun 2012. Industri kreatif juga diyakini dapat menjawab tantangan permasalahan dasar jangka pendek dan menengah, yaitu: (1) relatif rendahnya pertumbuhan ekonomi pasca krisis 2008; (2) masih tingginya angka pengangguran; (3) masih tingginya tingkat kemiskinan; dan (4) masih rendahnya daya saing industri di Indonesia (Kuncoro 2010).

PDB industri kreatif mampu tumbuh dengan tren rata-rata 5,12 persen pada periode tahun 2011-2013. Hal ini tidak mengherankan melihat potensi industri kreatif Indonesia yang sangat beragam. Department of Culture, Media, and Sport (DMCS) di Inggris juga menyatakan bahwa industri kreatif tumbuh paling tinggi di antara sektor industri lainnya (Garnham 2005).

Hal ini merupakan satu harapan baru bagi perekonomian Indonesia karena industri kreatif adalah industri yang sangat layak untuk dikembangkan dan memiliki peluang yang besar dalam membenahi perekonomian Indonesia (Sebayang 2012). Untuk dapat terus bersaing secara global, industri kreatif perlu didukung teknologi yang memadai sehingga dapat memproduksi barang dengan meningkatkan kualitas dan kuantitas. Pemerintah menargetkan PDB industri kreatif untuk terus meningkat agar dapat berkontribusi terhadap perekonomian hingga mencapai 9 persen dari PDB nasional. Disamping itu, total ekspor industri kreatif pada tahun 2009 (114 925 milyar rupiah) tidak mengalami penurunan dari tahun 2008 (95 209 milyar rupiah) seperti yang dialami oleh sektor Industri lainnya sebagai akibat dari krisis global. Berdasarkan latar belakang tersebut, maka perlu dilakukan penelitian terkait dengan pertumbuhan teknologi serta faktor yang memengaruhi PDB industri kreatif di Indonesia. Informasi yang diperoleh dari penelitian ini diharapkan dapat membantu dalam merumuskan strategi untuk mencapai target kontribusi PDB industri kreatif hingga 9 persen.

\section{Tujuan Penelitian}

Tujuan dari penelitian ini adalah:

1. Menganalisis kondisi dan kontribusi 14 subsektor industri kreatif Indonesia terhadap perekonomian Indonesia.

2. Menganalisis pertumbuhan teknologi (TFP) dari 14 subsektor industri kreatif Indonesia.

3.. Menganalisis faktor-faktor yang memengaruhi PDB sektor industri kreatif Indonesia.

4. Menganalisis hubungan kausalitas antara PDB dengan ekspor sektor industri kreatif Indonesia.

\section{METODE PENELITIAN Jenis dan Sumber Data}

Penelitian ini menggunkan data sekunder yaitu gabungan time series dengan periode tahun analisis 2006-2013 dan cross-section 14 subsektor industri kreatif, yaitu: (1) periklanan; arsitektur; (3) pasar barang seni; (4) kerajinan; (5) desain; (6) fesyen; (7) film, video, dan fotografi; (8) permainan interaktif; (9) musik; (10) seni pertunjukan; (11) penerbitan dan percetakan; (12) layanan komputer dan 
piranti lunak; (13) radio dan televisi; dan (14) riset dan pengembangan. Data yang digunakan yaitu PDB 14 subsektor industri kreatif, jumlah tenaga kerja 14 subsektor industri kreatif, jumlah usaha 14 subsektor industri kreatif, nilai ekspor 14 subsektor industri kreatif yang bersumber dari Kemenparekraf, serta jumlah SMK dan perguruan tinggi di Indonesia yang bersumber dari Badan Pusat Statistik (BPS).

\section{Metode Analisis Data}

Data yang diperoleh dalam penelitian dianalisis secara deskriptif dan kuantitatif. Metode deskriptif digunakan untuk menjelaskan kondisi dan kontribusi 14 subsektor industri kreatif terhadap perekonomian Indonesia, sedangkan metode kuantitatif untuk menghitung pertumbuhan teknologi yang diproksikan oleh TFP, menganalisis faktor-faktor yang memengaruhi PDB industri kreatif, dan menganalisis keterkaitan PDB dengan ekspor industri kreatif. Metode yang digunakan adalah analisis nilai TFP, regresi data panel, dan uji kausalitas Granger.

Analisis nilai TFP. Landasan teori pertumbuhan yang digunakan mengacu pada model pertumbuhan endogen yang memasukkan perubahan teknologi (TFP). TFP diukur secara tidak langsung (indirect accounting), karena tidak dapat diamati secara langsung (Mankiw 2007). Dalam penelitian ini, penghitungan TFP mengikuti metode yang digunakan oleh Mahyuddin et al (2006) sebagai berikut: $\mathrm{Y}=\mathrm{AL}^{a} \mathrm{~K}^{b}$....

Untuk keperluan perhitungan TFP, maka dilakukan transformasi logaritma terhadap fungsi produksi Cobb-Douglas, dengan tahapan sebagai berikut:

$$
\begin{array}{ll}
\mathrm{Y}_{2}-\mathrm{Y}_{1} & \mathrm{~A}_{2} \mathrm{~L}_{2}{ }^{a} \mathrm{~K}_{2}{ }^{b}-\mathrm{A}_{1} \mathrm{~L}_{1}{ }^{a} \mathrm{~K}_{1}{ }^{b} . \\
\frac{Y_{2}-Y_{1}}{Y_{1}} & =\frac{A_{2}}{A_{1}}\left(\frac{L_{2}}{L_{1}}\right)^{a}\left(\frac{K_{2}}{K_{1}}\right)^{b}-1 \ldots \ldots .
\end{array}
$$

$\frac{Y_{2}-Y_{1}}{Y_{1}}+1=\frac{A_{2}}{A_{1}}\left(\frac{L_{2}}{L_{1}}\right)^{a}\left(\frac{K_{2}}{K_{1}}\right)^{b}$

$\frac{Y_{2}}{Y_{1}} \quad=\frac{A_{2}}{A_{1}}\left(\frac{L_{2}}{L_{1}}\right)^{a}\left(\frac{K_{2}}{K_{1}}\right)^{b}$

$\ln \left(\frac{Y_{2}}{Y_{1}}\right) \quad=\ln \left(\frac{A_{2}}{A_{1}}\right)+\operatorname{aln}\left(\frac{L_{2}}{L_{1}}\right)+$

$\mathrm{Y}_{\mathrm{it}}{ }^{*} \quad=\mathrm{A}_{\mathrm{it}}{ }^{*}+a \mathrm{~L}_{\mathrm{it}}{ }^{*}+b \mathrm{~K}_{\mathrm{it}}{ }^{*}$

$\mathrm{A}_{\mathrm{it}}{ }^{*} \quad=\mathrm{Y}_{\mathrm{it}}{ }^{*}-\left(a \mathrm{~L}_{\mathrm{it}}{ }^{*}+b \mathrm{~K}_{\mathrm{it}}{ }^{*}\right)$

Dimana $\mathrm{Y}_{\text {it }}{ }^{*}$ adalah pertumbuhan output, $\mathrm{L}_{\mathrm{it}}{ }^{*}$ adalah pertumbuhan tenaga kerja, $\mathrm{K}_{\mathrm{it}}{ }^{*}$ adalah pertumbuhan modal, dan $\mathrm{A}_{\mathrm{it}}{ }^{*}$ adalah pertumbuhan TFP. Untuk mendapatkan nilai elastisitas tenaga kerja dan modal ( $a$ dan $b$ ) maka digunakan metode panel statis. Setelah mendapatkan nilai elastisitas tersebut, selanjutnya dilakukan penghitungan TFP sesuai dengan persamaan (8).

Panel Data. Panel data merupakan teknik regresi yang menggabungkan data time series dengan cross section. Karena mengkombinasikan data cross section dan time series, maka panel data memiliki beberapa keunggulan antara lain (Gujarati 2004):

- Mampu mengidentifikasi dan mengukur efek yang secara sederhana tidakdapat diatasi dalam data cross section murni atau data time series murni.

- Mampu mengontrol heterogenitas individu.

- Memberikan data yang informatif, mengurangi kolinearitas antar peubahserta meningkatkan derajat kebebasan sehingga data menjadi lebih efisien.

- Mampu menguji dan mengembangkan model perilaku yang lebihkompleks.

Dengan keunggulan tersebut, maka berimplikasi pada tidak harus dilakukannya pengujian asumsi klasik dalam model data panel. 
1. Perumusan Model

Variabel yang digunakan dalam penelitian ini berdasarkan indikator keberhasilan industri kreatif menurut Kemendag (2008) dan berdasarkan penelitian terdahulu, yaitu: (1) Zhang (2011) mengenai faktor-faktor yang memengaruhi pertumbuhan industri kreatif di Cina; (2) Rani (2011) mengenai dampak teknologi terhadap industri kreatif di India; dan (3) Mikic (2012) mengenai peran kebijakan pemerintah dalam industri kreatif di Serbia. Dugaan persamaan PDB industri kreatif Indonesia dirumuskan sebagai berikut:

$$
\begin{aligned}
\ln Y 1_{i t}= & \beta_{0}+\beta_{1} \ln X 1_{t}+\beta_{2} \ln X 2_{i t}+ \\
& \beta_{3} \ln X 3_{i t}+\beta_{4} X 4_{i t}+\beta_{5} \ln X 5_{t}+e_{i t}
\end{aligned}
$$

dimana:

$$
\begin{aligned}
& \mathrm{Y} 1_{\text {it }}=\mathrm{PDB} \text { subsektor industri kreatif } \\
& \text { subsektor i pada tahun ke-t } \\
& \text { (rupiah) } \\
& \mathrm{X} 1_{\mathrm{t}}=\text { Jumlah SMK di Indonesia pada } \\
& \text { tahun ke-t (unit) } \\
& \mathrm{X} 2_{\text {it }}=\text { Jumlah usaha industri kreatif } \\
& \text { subsektor i tahun ke-t (unit) }
\end{aligned}
$$

2. Uji Pemilihan Model

- Chow Test

Hipotesis dari uji ini yaitu:

$\mathrm{H}_{0}$ : Model pooled least square

$\mathrm{H}_{1}$ : Model fixed effect

Jika hasil dari Chow Test signifikan (probability dari Chow $<\alpha$ ), maka $\mathrm{H}_{0}$ ditolak yang artinya Fixed Effect digunakan.

\section{- Hausman Test}

Hipotesis dari uji ini yaitu:

$\mathrm{H}_{0}$ : Model random effect

$\mathrm{H}_{1}$ : Model fixed effects

Jika nilai statistik hasil pengujian lebih besar dari Chi square tabel, maka cukup bukti untuk melakukan penolakan terhadap $\mathrm{H}_{0}$ sehingga pendekatan yang digunakan adalah fixed effect model.

3. Uji Kesesuaian Model

- Uji-F

Uji-F adalah statistik uji yang digunakan untuk mengetahui bagaimana pengaruh peubah eksogen terhadap peubah endogen secara keseluruhan.

$\mathrm{H}_{0}: \beta_{1}=\beta_{2}=\ldots=\beta_{\mathrm{n}}=0$

$\mathrm{H}_{1}$ : minimal ada satu $\beta_{\mathrm{n}} \neq 0$

Jika probabilitas $F$-statistic $<\alpha$, maka tolak $\mathrm{H}_{0}$. Kesimpulannya, minimal ada satu variabel eksogen yang memengaruhi variabel endogen.

- Uji-t

Uji-t dalam penelitian ini digunakan untuk mengetahui pengaruh masingmasing variabel eksogen terhadap PDB industri kreatif Indonesia.

$\mathrm{H}_{0}: \beta_{\mathrm{t}}=0$ dengan $\mathrm{t}=1,2,3, \ldots, \mathrm{n}$

$\mathrm{H}_{1}: \beta_{\mathrm{t}} \neq 0$

Jika probabilitas $t$-statistic $<\alpha$, maka tolak $\mathrm{H}_{0}$. Kesimpulannya, variabel yang diuji berpengaruh nyata terhadap variabel endogen.

- $\quad \mathbf{U j i} \mathbf{R}^{\mathbf{2}}$

Uji ini dilakukan untuk melihat sejauh mana besar keragaman yang dapat dijelaskan oleh variabel eksogen terhadap variabel endogen.Nilai $\mathrm{R}^{2}$ berkisar antara 0 sampai dengan 1 , semakin mendekati satu maka semakin baik.

Uji Kausalitas Granger. Dalam penelitian ini, akan dianalisis mengenai hubungan kausalitas antara PDB dengan ekspor seperti penelitian yang dilakukan oleh Mehrara dan Firouzjaee (2011). Kausalitas adalah hubungan dua arah. 
Dengan demikian, jika terjadi kausalitas di dalam model ekonometrika ini tidak terdapat variabel independen, semua variabel merupakan variabel dependen (Winarno 2009). Hipotesis dalam penelitian ini yaitu:

- $\mathrm{H}_{0}$ : PDB tidak mempengaruhi ekspor

$\mathrm{H}_{1}$ : PDB mempengaruhi ekspor

- $\mathrm{H}_{0}$ : Ekspor tidak mempengaruhi PDB

$\mathrm{H}_{1}$ : Ekspor mempengaruhi PDB

\section{HASIL DAN PEMBAHASAN}

\section{Analisis Kondisi dan Kontribusi 14 Subsektor Industri Kreatif Indonesia terhadap Perekonomian Indonesia}

\section{Periklanan}

Industri kreatif periklanan telah didukung pemerintah. Hal ini dapat dilihat dari adanya apresiasi terhadap industri periklanan dalam negeri. Penghargaan diadakan secara berkelanjutan pada skala regional (daerah) yaitu Jawa Pos Ad Festival yang merupakan ajang pemberian penghargaan terhadap karya iklan media cetak terbaik Jawa Pos dan skala nasional yaitu Citra Pariwara. Namun, dukungan pemerintah masih kurang bagi para pelaku industri kreatif periklanan untuk mengikuti ajang penghargaan pariwara berskala internasional yaitu ADFEST (Asia Pasific Advertising Festival). Hal ini merupakan salah satu penyebab masih rendahnya kontribusi ekspor industri periklanan seperti yang dapat dilihat pada Tabel 1. Untuk kontribusi ekspor dan jumlah usaha, industri periklanan menempati urutan ke-13 dari 14 subsektor industri kreatif, sedangkan untuk kontribusi PDB dan jumlah tenaga kerja menempati urutan ke-12.

Tabel 1 menunjukkan bahwa walaupun kontribusi industri periklanan dalam PDB industri kreatif belum mencapai 1 persen, namun pertumbuhan PDB nya tinggi yaitu mencapai 8 persen pada tahun 2013. Hal ini disebabkan oleh keberadaan PPPI (Persatuan Perusahaan Periklanan Indonesia) yang merupakan asosiasi profesi dan asosiasi industri periklanan yang aktif sehingga menciptakan sirkulasi informasi di antara pelaku dalam industri periklanan. Dengan adanya sirkulasi informasi yang baik, industri periklanan dapat tumbuh dengan tinggi.

Tabel 1 Kontribusi subsektor industri periklanan

\begin{tabular}{|c|c|c|}
\hline Indikator & Satuan & 2013 \\
\hline \multicolumn{3}{|c|}{ Berbasis Produk Domestik Bruto (PDB) } \\
\hline Nilai Tambah & Rp Milyar & 1531,6 \\
\hline$\%$ thd Ind.Kreatif & Persen & 0,99 \\
\hline$\Delta$ Nilai Tambah & Persen & 8,01 \\
\hline$\%$ thd Total PDB & Persen & 0,057 \\
\hline \multicolumn{3}{|c|}{ Berbasis Ketenagakerjaan } \\
\hline Jumlah TK & Orang & 20600 \\
\hline$\%$ thd Ind. Kreatif & Persen & 0,25 \\
\hline$\%$ thd Total TK & Persen & 0,019 \\
\hline$\Delta$ Jumlah TK & Persen & 2,74 \\
\hline Produktivitas TK & Rp Ribu & 74350 \\
\hline \multicolumn{3}{|c|}{ Berbasis Nilai Ekspor } \\
\hline Nilai Ekspor & Rp Juta & 19932 \\
\hline$\Delta$ Ekspor & Persen & 5,52 \\
\hline$\%$ thd Ind.Kreatif & Persen & 0,019 \\
\hline$\%$ thd Total Ekspor & Persen & 0,001 \\
\hline \multicolumn{3}{|c|}{ Berbasis Jumlah Usaha } \\
\hline Jumlah Usaha & Unit & 2560 \\
\hline$\Delta$ Jumlah Usaha & Persen & 2,86 \\
\hline$\%$ thd Ind.Kreatif & Persen & 0,11 \\
\hline$\%$ thd Total Usaha & Persen & 0,005 \\
\hline \multicolumn{3}{|c|}{ Sumber: Kemenparekraf (2013) (diolah) } \\
\hline \multicolumn{3}{|c|}{$\begin{array}{l}\text { Untuk mendukung industri } \\
\text { periklanan agar dapat terus tumbuh, } \\
\text { pemerintah telah menerbitkan Permen } \\
\text { Kominfo No.25 Tahun } 2007 \text { tentang } \\
\text { penggunaan sumberdaya domestik untuk } \\
\text { produk iklan, di lembaga penyiaran, } \\
\text { pemerintah juga tidak terlalu membatasi } \\
\text { produsen pembuat iklan mengingat tidak }\end{array}$} \\
\hline
\end{tabular}


banyak produsen iklan dalam negeri yang unggul dalam kualitas karena jam terbangnya masih rendah. Disamping itu, sudah ada lembaga pembiayaan bukan bank yang dapat digunakan sebagai sumber pendanaan bagi industri periklanan ini yaitu Penanaman Modal Madani milik BUMN dan Komisi Penyiaran Indonesia milik KADIN, namun belum ada dukungan dari bank.

\section{Arstitektur}

Kontribusi industri arsitektur terhadap perekonomian dapat dilihat pada Tabel 2. Industri arsitektur menempati urutan ke-11 untuk kontribusi ekspor, urutan ke-6 untuk kontribusi PDB, urutan ke-12 untuk kontribusi jumlah usaha, dan urutan ke10 untuk kontribusi jumlah tenaga kerja dari 14 subsektor industri kreatif.

Tabel 2 Kontribusi subsektor industri arsitektur

\begin{tabular}{|c|c|c|}
\hline Indikator & Satuan & 2013 \\
\hline \multicolumn{3}{|c|}{ Berbasis Produk Domestik Bruto (PDB) } \\
\hline Nilai Tambah & Rp Milyar & 5503,3 \\
\hline$\%$ thd Ind. Kreatif & Persen & 3,57 \\
\hline$\Delta$ Nilai Tambah & Persen & 8,04 \\
\hline$\%$ thd Total PDB & Persen & 0,203 \\
\hline \multicolumn{3}{|c|}{ Berbasis Ketenagakerjaan } \\
\hline Jumlah TK & Orang & 42670 \\
\hline$\%$ thd Ind. Kreatif & Persen & 0,52 \\
\hline$\%$ thd Total TK & Persen & 0,04 \\
\hline$\Delta$ Jumlah TK & Persen & 1,30 \\
\hline Produktivitas TK & Rp Ribu & 129020 \\
\hline \multicolumn{3}{|l|}{ Berbasis Nilai Ekspor } \\
\hline Nilai Ekspor & Rp Juta & 104258 \\
\hline$\Delta$ Ekspor & Persen & 4,48 \\
\hline$\%$ thd Ind.Kreatif & Persen & 0,10 \\
\hline$\%$ thd Total Ekspor & Persen & 0,005 \\
\hline \multicolumn{3}{|c|}{ Berbasis Jumlah Usaha } \\
\hline Jumlah Usaha & Unit & 3869 \\
\hline$\Delta$ Jumlah Usaha & Persen & 1,21 \\
\hline$\%$ thd Ind.Kreatif & Persen & 0,16 \\
\hline$\%$ thd Total Usaha & Persen & 0,007 \\
\hline
\end{tabular}

Sumber: Kemenparekraf (2013) (diolah)
Ikatan Arsitektur Indonesia (IAI) sudah mengadakan ajang penghargaan bagi para arsitek Indonesia. Hal ini agar memacu para arsitek Indonesia untuk terus berkarya agar dapat mendorong industri arsitektur sehingga dapat tumbuh mencapai 8 persen pada tahun 2013.

Akibat globalisasi, peningkatan kompetensi tenaga kerja terdidik yang mampu bersaing merupakan kebutuhan mendasar. Oleh karena itu, sejak tahun 2008 telah dibuka pendidikan profesi arsitektur setelah lulus dari strata 1 (sarjana) sebagai respon atas kebutuhan industri karena kurikulum pendidikan arsitektur 4 tahun dirasa kurang memadai untuk mencetak arsitek yang berkualitas.

Dalam industri kreatif, HKI merupakan landasan utama sebagai perlindungan hasil kreasi dari pelaku industri kreatif, salah satunya arsitek yang telah diatur dalam Undang-Undang No. 19 Tahun 2002 tentang Hak Cipta. Namun, di sisi lain, dukungan pemerintah untuk mengirimkan arsitek dalam negeri untuk mengikuti ajang sayembara atau pameran di luar negeri masih kurang. Padahal, keikutsertaan arsitek Indonesia ke luar negeri sangatlah penting sebagai sarana promosi. Hal ini tentunya dapat meningkatkan ekspor jasa arsitek dalam negeri yang masih rendah kontribusinya seperti yang terlihat pada Tabel 2 . Disamping itu, juga belum ada lembaga pembiayaan yang mendukung industri ini karena kendala agunan untuk mendapat pedanaan.

\section{Pasar Barang Seni}

Kemenparekraf

menyatakan bahwa bisnis di bidang seni memiliki prospek cerah. Pasar Seni Ancol adalah suatu permodelan dari suatu pengkemasan klaster pasar barang seni. Namun, saat ini pasar seni belum tergarap optimal karenalandasan 
pendidikan seni di sekolah umum belum tersentuh sehingga sumber daya yang berkualitas di bidang seni masih terbatas. Hal ini berdampak pada masih rendahnya kontribusi industri pasar barang seni seperti yang terlihat pada Tabel 3. Industri pasar barang seni menempati urutan ke-11 untuk kontribusi jumlah usaha, urutan ke-3 untuk kontribusi jumlah tenaga kerja, dan urutan terakhir untuk kontribusi PDB dan ekspor.

Tabel 3 Kontribusi subsektor industri pasar barang seni

\begin{tabular}{|c|c|c|}
\hline Indikator & Satuan & 2013 \\
\hline \multicolumn{3}{|c|}{ Berbasis Produk Domestik Bruto (PDB) } \\
\hline Nilai Tambah & Rp Milyar & 456,1 \\
\hline$\%$ thd Ind. Kreatif & Persen & 0,29 \\
\hline$\Delta$ Nilai Tambah & Persen & 4,07 \\
\hline$\%$ thd Total PDB & Persen & 0,017 \\
\hline \multicolumn{3}{|c|}{ Berbasis Ketenagakerjaan } \\
\hline Jumlah TK & Orang & 15269 \\
\hline$\%$ thd Ind. Kreatif & Persen & 0,19 \\
\hline$\%$ thd Total TK & Persen & 0,014 \\
\hline$\Delta$ Jumlah TK & Persen & 0,21 \\
\hline Produktivitas TK & Rp Ribu & 29870 \\
\hline \multicolumn{3}{|l|}{ Berbasis Nilai Ekspor } \\
\hline Nilai Ekspor & Rp Juta & 11405 \\
\hline$\Delta$ Ekspor & Persen & 3,78 \\
\hline$\%$ thd Ind.Kreatif & Persen & 0,011 \\
\hline$\%$ thd Total Ekspor & Persen & 0,0006 \\
\hline \multicolumn{3}{|c|}{ Berbasis Jumlah Usaha } \\
\hline Jumlah Usaha & Unit & 5242 \\
\hline$\Delta$ Jumlah Usaha & Persen & 1,84 \\
\hline$\%$ thd Ind.Kreatif & Persen & 0,22 \\
\hline$\%$ thd Total Usaha & Persen & 0,01 \\
\hline
\end{tabular}

Kebijakan pemerintah dalam industri pasar barang seni masih belum terarah. Masih terjadi penggusuran di kawasan perdagangan barang seni seperti pedagang keramik di Rawasari, Jakarta Pusat. Disamping itu, belum ada HKI sehingga masih banyak terjadi pembajakan. Peran lembaga pembiayaan juga belum mendukung industri
ini.Lembaga pembiayaan biasanya lebih berperan pada pameran yang dijembatani oleh galeri.Untuk seniman muda, hal ini masih merupakan kendala karena belum banyak galeri yang mau membiayai.

\section{Kerajinan}

Pada tahun 2013, industri kerajinan menyumbang PDB industri kreatif hingga 15,1 persen seperti yang ditunjukkan pada Tabel 4. Industri kerajinan menempati urutan ke-2 dari 14 subsektor industri kreatif untuk seluruh kontribusi perekonomian (PDB, ekspor, jumlah usaha, dan jumlah tenaga kerja).

Tabel 4 Kontribusi subsektor industri kerajinan

\begin{tabular}{|c|c|c|}
\hline Indikator & Satuan & 2013 \\
\hline \multicolumn{3}{|c|}{ Berbasis Produk Domestik Bruto (PDB) } \\
\hline Nilai Tambah & Rp Milyar & 25348 \\
\hline$\%$ thd Ind. Kreatif & Persen & 15,1 \\
\hline$\Delta$ Nilai Tambah & Persen & 6,38 \\
\hline$\%$ thd Total PDB & Persen & 0,94 \\
\hline \multicolumn{3}{|c|}{ Berbasis Ketenagakerjaan } \\
\hline Jumlah TK & Ribu orang & 3109 \\
\hline$\%$ thd Ind. Kreatif & Persen & 38,2 \\
\hline$\%$ thd Total TK & Persen & 2,90 \\
\hline$\Delta$ Jumlah TK & Persen & 1,04 \\
\hline Produktivitas TK & Rp Ribu & 8155 \\
\hline \multicolumn{3}{|c|}{ Berbasis Nilai Ekspor } \\
\hline Nilai Ekspor & Rp Milyar & 21723 \\
\hline$\Delta$ Ekspor & Persen & 7,67 \\
\hline$\%$ thd Ind.Kreatif & Persen & 20,27 \\
\hline$\%$ thd Total Ekspor & Persen & 1,05 \\
\hline \multicolumn{3}{|c|}{ Berbasis Jumlah Usaha } \\
\hline Jumlah Usaha & Ribu unit & 1076 \\
\hline$\Delta$ Jumlah Usaha & Persen & 0,46 \\
\hline$\%$ thd Ind.Kreatif & Persen & 45,2 \\
\hline$\%$ thd Total Usaha & Persen & 2,03 \\
\hline
\end{tabular}

Sumber: Kemenparekraf (2013) (diolah)

Hal ini tidak mengherankan melihat etnis suku bangsa Indonesia yang merupakan sumber kreativitas yang tidak akan ada habisnya. Industri kerajinan mampu bertahan ketika krisis 2008 karena minimnya ketergantungan 
akan komponen impor. Daerah-daerah yang sudah kuat imagenya dalam turisme seperti Bali, Yogyakarta, dan Batam menjadi peluang untuk jalur distribusi industri ini. Jumlah penduduk Indonesia yang banyak juga merupakan potensi pasar, namun apresiasi masyarakat terhadap produk kerajinan masih kurang karena rendahnya daya beli sehingga masih memprioritaskan harga dan fungsi produk. Disisi lain, produktivitas tenaga kerjanya masih rendah karena masih minimnya upah seperti yang ditunjukkan pada Tabel 4.

Dalam rangka memperkenalkan produk kerajinan Indonesia di kalangan luar negeri, Kemendag telah mengoordinasi promosi di luar negeri. Hal ini berdampak pada tingginya kontribusi ekspor produk kerajinan Indonesia yang mencapai 21,7 triliun rupiah atau mencapai hampir 1 persen dari total ekspor Indonesia pada tahun 2013.

Untuk memudahkan para pelaku industri kerajinan untuk terus berkarya, Presiden telah meluncurkan Kredit Usaha Rakyat (KUR) tanpa agunan pada tanggal 5 November 2007. Namun, hal ini belum dapat dioptimalkan manfaatnya oleh industri kreatif karena kendala perbedaan karakteristik bisnis sektor industri kreatif dengan sektor industri lainnya (Khristianto 2008). Disisi lain, pemerintahjuga masih lemah dalam menegakkan hukum terhadap pelaku ekspor kayu ilegal yang masih banyak dilakukan di daerah-daerah seperti perbatasan Kalimantan dan Malaysia. Hal ini akan mempengaruhi ketersediaan bahan baku untuk industri kerajinan domestik.

\section{Desain}

Pada tahun 2013, industri desain mampu menyumbang 6,7 persen PDB industri kreatif seperti yang ditunjukkan pada Tabel 5. Industri desain menempati urutan ke-4 untuk kontribusi PDB, jumlah tenaga kerja, dan ekspor, sedangkan untuk kontribusi jumlah usaha menempati urutan ke-5 dari 14 subsektor industri kreatif.

Tabel 5 menunjukan bahwa tingkat partisipasi tenaga kerja di bidang desain baru mencapai sekitar 2 persen, padahal industri desain berpeluang besar untuk menyerap lebih banyak tenaga kerja. Hal ini dikarenakan masih minimnya sumber daya yang berkualitas di bidang desain. Pendidikan desain di Indonesia memang semakin populer, namun biaya pendidikan di sekolah desain masih mahal. Disamping itu, desainer-desainer lokal lebih senang bekerja di luar negeri karena insentif yang lebih tinggi.

Tabel 5 Kontribusi subsektor industri desain

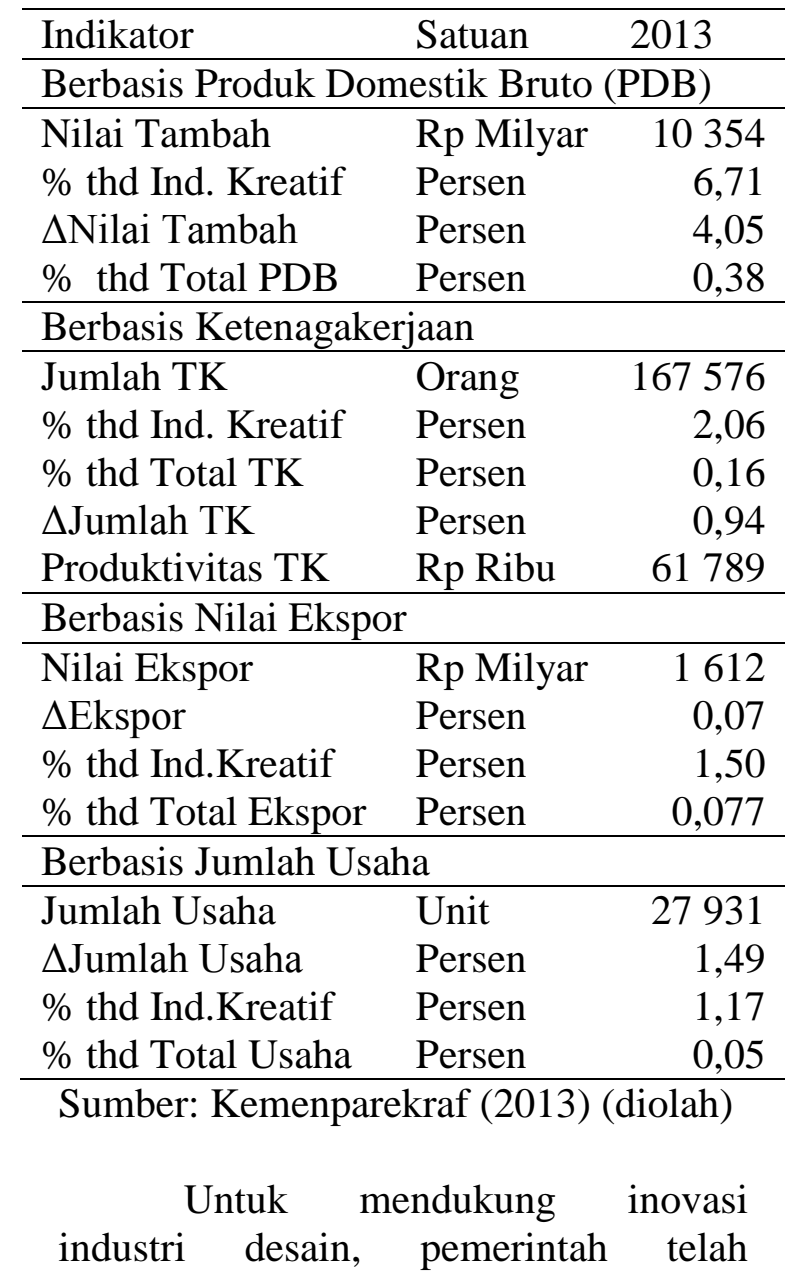


menerbitkan peraturan pemerintah No. 35 Tahun 2007 mengenai insentif pengurangan pajak bagi BUMN seperti LIPI, BPPT, dan PUSPITEK yang melakukan kegiatan R\&D.

\section{Fesyen}

Industri fesyen merupakan subsektor industri kreatif yang berkontribusi paling tinggi dalam hal PDB, tenaga kerja, jumlah usaha, dan ekspor seperti yang dapat dilihat pada Tabel 6. Hal ini tidak mengherankan mengingat industri fesyen Indonesia sudah layak bersaing di kancah global, khususnya karena telah berhasil memenuhi kriteria ramah lingkungan. Keuntungan bagi Indonesia adalah memiliki banyak serat alam dan banyak juga yang menggunakan bahan daur ulang untuk produk fesyen.

Tabel 6 Kontribusi subsektor industri fesyen

\begin{tabular}{|c|c|c|}
\hline Indikator & Satuan & 2013 \\
\hline \multicolumn{3}{|c|}{ Berbasis Produk Domestik Bruto (PDB) } \\
\hline Nilai Tambah & Rp Milyar & 65097 \\
\hline$\%$ thd Ind. Kreatif & Persen & 42,18 \\
\hline$\Delta$ Nilai Tambah & Persen & 6,44 \\
\hline$\%$ thd Total PDB & Persen & 2,40 \\
\hline \multicolumn{3}{|c|}{ Berbasis Ketenagakerjaan } \\
\hline Jumlah TK & Ribu orang & 3838 \\
\hline$\%$ thd Ind. Kreatif & Persen & 47,2 \\
\hline$\%$ thd Total TK & Persen & 3,59 \\
\hline$\Delta$ Jumlah TK & Persen & 0,77 \\
\hline Produktivitas TK & Rp Ribu & 16957 \\
\hline \multicolumn{3}{|l|}{ Berbasis Nilai Ekspor } \\
\hline Nilai Ekspor & Rp Milyar & 76788 \\
\hline$\Delta$ Ekspor & Persen & 9,51 \\
\hline$\%$ thd Ind.Kreatif & Persen & 71,7 \\
\hline$\%$ thd Total Ekspor & Persen & 3,71 \\
\hline \multicolumn{3}{|c|}{ Berbasis Jumlah Usaha } \\
\hline Jumlah Usaha & Ribu unit & 1107 \\
\hline$\Delta$ Jumlah Usaha & Persen & 0,53 \\
\hline$\%$ thd Ind.Kreatif & Persen & 46,5 \\
\hline$\%$ thd Total Usaha & Persen & 2,09 \\
\hline
\end{tabular}

Tabel 6 menunjukkan bahwa nilai ekspornya tahun 2013 mencapai 76 triluin rupiah, meningkat 9,51 persen dari pencapaian tahun 2012. Hal ini menunjukkan bahwa fesyen adalah salah satu produk ekspor nonmigas yang potensial dari Indonesia. Disamping itu, berkembangnya industri fesyen membawa dampak positif terhadap penyerapan tenaga kerja yang hampir mencapai 4 juta orang. Industri fesyen juga mendominasi jumlah usaha industri kreatif dengan persentase 46,5 persen. Barier to entry bisnis distro dan UKM/IKM di bidang fesyen relatif kecil, sehingga ini menjadi penyumbang terbesar jumlah perusahaan di industri kreatif.

Potensi industri fesyen lokal yang begitu besar dan antusiasme insan mode melatarbelakangi tercetusnya Indonesia Fashion Week (IFW) yang diselanggarakan oleh APPMI (Asosiasi Perancang Pengusaha Mode Indonesia). Ajang ini bertujuan untuk menanamkan mindset masyarakat Indonesia bahwa produk lokal sama hebatnya dengan produk luar. Kemendag juga tengah mengupayakan penguatan branding produk fesyen lokal, sebagai upaya menjadikan Indonesia sebagai fashion hub dunia pada tahun 2025.

Pemerintah turut mendukung industri fesyen dengan menetapkan pajak sekitar 25 persen untuk ekspor kulit mentah agar industri tidak kesulitan bahan baku. Disisi lain, kebutuhan akan HKI tidak terlalu penting karena perubahan dalam fesyen sangat cepat. Kondisi yang sering terjadi justru pemalsuan merek. Pengrajin sepatu lokal mampu menduplikasi sepatu-sepatu merk terkenal dengan kualitas yang tidak jauh berbeda.

\section{Film, Video, dan Fotografi}

Dari 14 subsektor industri kreatif, industri film, video dan fotografi 
menempati urutan ke-4 untuk kontribusi jumlah usaha, urutan ke-8 untuk kontribusi jumlah tenaga kerja dan ekspor, dan urutan ke-9 untuk kontribusi PDB. Walaupun kontribusinya masih rendah, Industri ini memiliki potensi yang besar dari segi bisnis karena dapat tumbuh mencapai 6,27 persen pada tahun 2013 seperti yang terlihat pada Tabel 7. Namun, masalah terbesar dalam industri ini adalah maraknya pelanggaran hak cipta film, khususnya pembajakan. Law enforcement serta regulasi produksi film yang ada saat ini belum atau bahkan tidak maksimal sama sekali sehingga tindakan pembajakan seolah tidak pernah dikenai sanksi hukum.

Tabel 7 Kontribusi subsektor film, video, dan fotografi

\begin{tabular}{llr}
\hline Indikator & Satuan & \multicolumn{1}{c}{2013} \\
\hline \multicolumn{3}{l}{ Berbasis Produk Domestik Bruto (PDB) } \\
\hline Nilai Tambah & Rp Milyar & 3145 \\
$\%$ thd Ind. Kreatif & Persen & 2,04 \\
$\Delta$ Nilai Tambah & Persen & 6,27 \\
$\%$ thd Total PDB & Persen & 0,12 \\
\hline
\end{tabular}

Berbasis Ketenagakerjaan

\begin{tabular}{|c|c|c|}
\hline Jumlah TK & Orang & 63755 \\
\hline$\%$ thd Ind. Kreatif & Persen & 0,78 \\
\hline$\%$ thd Total TK & Persen & 0,06 \\
\hline$\Delta$ Jumlah TK & Persen & 2,02 \\
\hline Produktivitas TK & Rp Ribu & 49335 \\
\hline \multicolumn{3}{|l|}{ Berbasis Nilai Ekspor } \\
\hline Nilai Ekspor & Rp Juta & 639438 \\
\hline$\Delta$ Ekspor & Persen & 4,43 \\
\hline$\%$ thd Ind.Kreatif & Persen & 0,60 \\
\hline$\%$ thd Total Ekspor & Persen & 0,03 \\
\hline \multicolumn{3}{|c|}{ Berbasis Jumlah Usaha } \\
\hline Jumlah Usaha & Unit & 29785 \\
\hline$\Delta$ Jumlah Usaha & Persen & 2,74 \\
\hline$\%$ thd Ind.Kreatif & Persen & 1,25 \\
\hline$\%$ thd Total Usaha & Persen & 0,06 \\
\hline
\end{tabular}

Sumber: Kemenparekraf (2013) (diolah)

Golongan masyarakat kelas menengah (middle class) di Indonesia yang semakin tumbuh pesat juga menjadi peluang bagi industri ini karena berdampak kepada peningkatan konsumsi tersier, dimana film adalah salah satunya. Akan tetapi, potensi tersebut belum didukung dengan jumlah layar bioskop yang cukup untuk penonton nasional. Di Indonesia, hanya ada 675 bioskop untuk melayani 246 juta penduduk. Penonton film masih terkonsentrasi di Jabodetabek, sejalan dengan terkonsentrasinya distribusi bioskop. Industri ini membutuhkan infrastruktur yang baik dan memadai. Saat ini, yang membangun bioskop hanya pengusaha saja, padahal butuh dukungan dari pemerintah.

Kuantitas film nasional cukup banyak, namun tidak diikuti dari dengan kualitas yang baik sehingga hanya segelintir film nasional yang memasuki daftar box office hollywood. Hal ini dikarenakan kurang kayanya tema film Indonesia. Insentif pekerja film juga masih rendah, sangat timpang dibanding pemeran. Disamping itu, jumlah sekolah film hanya satu yaitu Institut Kesenian Jakarta (IKJ). Kondisi ini praktis menyebabkan para pembuat film harus melatih sendiri para pekerja kreatif yang dibutuhkan. Untuk mendorong para pembuat film untuk terus berkarya, saat ini sudah ada festival film independen yang ditayangkan di bioskop dan juga ajang apresiasi (Indonesia Movie Award) yang digelar setiap tahun.

\section{Permainan Interaktif}

Fakta bahwa hampir di setiap komputer, telepon genggam, dan mall terdapat permainan interaktif menunjukkan bahwa industri ini memiliki potensi besar di dalam negeri. Keberadaan komunitas-komunitas online game merupakan potensi untuk membangun asosiasi permainan interaktif tingkat nasional. Eksistensi para pengembang permainan interaktif pun semakin diakui. Ini tampak dari masuknya kategori pengembangan 
permainan interaktif dalam ajang INAICTA (Indonesian ICT Award). Namun, kontribusi industri permainan interaktif terhadap perekonomian belum signifikan seperti yang dapat dilihat pada Tabel 8. Dari 14 subsektor industri kreatif, industri ini menempati urutan ke10 untuk kontribusi ekspor dan jumlah usaha, sedangkan untuk kontribusi PDB dan jumlah tenaga kerja menempati urutan ke-11.

Untuk mendorong pertumbuhan industri ini, pemerintah melalui Kementerian Komunikasi dan Informasi telah mengupayakan peralatan bersama agar terjadi cost sharing dari pelaku industri sehingga daya saing menjadi tinggi dan kebutuhan modal yang diperlukan menjadi rendah. Hal ini sebagai respon dari harga piranti lunak dan peralatan komputasi yang mahal.

Tabel 8 Kontribusi subsektor industri permainan interaktif

\begin{tabular}{|c|c|c|}
\hline Indikator & Satuan & 2013 \\
\hline \multicolumn{3}{|c|}{ Berbasis Produk Domestik Bruto (PDB) } \\
\hline Nilai Tambah & Rp Milyar & 1972 \\
\hline$\%$ thd Ind. Kreatif & Persen & 1,28 \\
\hline$\Delta$ Nilai Tambah & Persen & 6,34 \\
\hline$\%$ thd Total PDB & Persen & 0,07 \\
\hline \multicolumn{3}{|c|}{ Berbasis Ketenagakerjaan } \\
\hline Jumlah TK & Orang & 23928 \\
\hline$\%$ thd Ind. Kreatif & Persen & 0,29 \\
\hline$\%$ thd Total TK & Persen & 0,02 \\
\hline$\Delta$ Jumlah TK & Persen & 0,84 \\
\hline Produktivitas TK & Rp Ribu & 82418 \\
\hline \multicolumn{3}{|c|}{ Berbasis Nilai Ekspor } \\
\hline Nilai Ekspor & Rp Juta & 593039 \\
\hline$\Delta$ Ekspor & Persen & 0,85 \\
\hline$\%$ thd Ind.Kreatif & Persen & 0,55 \\
\hline$\%$ thd Total Ekspor & Persen & 0,03 \\
\hline \multicolumn{3}{|c|}{ Berbasis Jumlah Usaha } \\
\hline Jumlah Usaha & Unit & 7771 \\
\hline$\Delta$ Jumlah Usaha & Persen & 2,87 \\
\hline$\%$ thd Ind.Kreatif & Persen & 0,33 \\
\hline$\%$ thd Total Usaha & Persen & 0,015 \\
\hline
\end{tabular}

Sumber: Kemenparekraf (2013) (diolah)
Industri permainan interaktif membutuhkan sumber daya berkualitas yang mahir dalam bidang ini. Akan tetapi, belum banyak lembaga pendidikan formal yang mengkhususkan diri pada bidang permainan interaktif. Di Indonesia, ada ITB yang memiliki program srata 2 untuk game technology dan BINUS untuk program strata 1 . Disamping itu, belum banyak lembaga pembiayaan yang tertarik untuk mendanai sektor ini karena waktu kembalinya cukup lama.

\section{Musik}

Penyanyi dan band-band baru semakin banyak terbentuk, sementara penyanyi dan band senior masih tetap eksis. Jumlah insan kreatif musik tak pernah berhenti bertambah di Indonesia. Banyaknya ajang kompetisi yang marak saat ini seperti Indonesian Idol, AFI, KDI, dan lain-lain merupakan potensi bagi industri musik untuk terus tumbuh.

Melihat potensi yang dimiliki oleh industri musik Indonesia, seharusnya industri musik dapat menyumbang PDB industri kreatif lebih banyak dari saat ini yang hanya berkontribusi 1,57 persen seperti yang terlihat pada Tabel 9 atau berada pada urutan ke-10 dari 14 subsektor industri kreatif. Sementara itu, industri ini menempati urutan ke-7 untuk kontribusi jumlah usaha juga ekspor dan urutan ke9 untuk kontribusi jumlah tenaga kerja.

Seiring dengan pertumbuhan industri musik yang tumbuh 4,37 persen pada tahun 2013, sekolah musik bertambah jumlahnya meskipun masih terkonsentrasi di kota-kota besar. Agar para insan kreatif musik terus berkarya, sudah ada ajang apresiasi untuk musisi yang karyanya berkualitas. Java Jazz Festival yang diadakan rutin setiap tahun mendatangkan para pemusik jazz kelas dunia dan berkolaborasi dengan musisimusisi lokal sehingga pemusik Indonesia semakin dikenal dunia. Disamping itu, 
sistem royalti dalam industri musik membuat para musisi berpacu untuk berkreasi, karena jerih payah mereka akan lebih dihargai secara berkelanjutan.

$$
\text { Dalam industri musik, }
$$
pembajakan merupakan ancaman. Menurut data ASIRI 2007, penjualan musik bajakan mencapai 95,7 persen sementara musik legal hanya tinggal 4,3 persen. Hal ini menunjukkan gagalnya penegakan terhadap UU No.19 Tahun 2002 tentang hak cipta.

Tabel 9 Kontribusi subsektor industri musik

\begin{tabular}{|c|c|c|}
\hline Indikator & Satuan & 2013 \\
\hline \multicolumn{3}{|c|}{ Berbasis Produk Domestik Bruto (PDB) } \\
\hline Nilai Tambah & Rp Milyar & 2420 \\
\hline$\%$ thd Ind. Kreatif & Persen & 1,57 \\
\hline$\Delta$ Nilai Tambah & Persen & 4,37 \\
\hline$\%$ thd Total PDB & Persen & 0,089 \\
\hline \multicolumn{3}{|c|}{ Berbasis Ketenagakerjaan } \\
\hline Jumlah TK & Orang & 55958 \\
\hline$\%$ thd Ind. Kreatif & Persen & 0,69 \\
\hline$\%$ thd Total TK & Persen & 0,05 \\
\hline$\Delta$ Jumlah TK & Persen & 1,69 \\
\hline Produktivitas TK & Rp Ribu & 43255 \\
\hline \multicolumn{3}{|l|}{ Berbasis Nilai Ekspor } \\
\hline Nilai Ekspor & Rp Juta & 934236 \\
\hline$\Delta$ Ekspor & Persen & 2,24 \\
\hline$\%$ thd Ind.Kreatif & Persen & 0,87 \\
\hline$\%$ thd Total Ekspor & Persen & 0,05 \\
\hline \multicolumn{3}{|c|}{ Berbasis Jumlah Usaha } \\
\hline Jumlah Usaha & Unit & 16182 \\
\hline$\Delta$ Jumlah Usaha & Persen & 2,40 \\
\hline$\%$ thd Ind.Kreatif & Persen & 0,68 \\
\hline$\%$ thd Total Usaha & Persen & 0,03 \\
\hline
\end{tabular}

\section{Seni Pertunjukan}

Kelompok kesenian di Indonesia sudah cukup banyak, yaitu berjumlah 87 ribu kelompok. Namun, kontribusi PDB industri seni pertunjukan terhadap perekonomian kreatif masih belum mencapai 1 persen seperti yang telihat pada Tabel 10 atau masih menempati urutan ke-13 dari 14 subsektor industri kreatif, sedangkan untuk kontribusi jumlah tenaga kerja dan jumlah usaha menempati urutan ke-6 dan urutan ke-10 untuk kontribusi ekspor.

Industri seni pertunjukan ini berhadapan langsung dengan barang substitusi lain yaitu hiburan tontonan lain seperti televisi dan film. Hal ini menyebabkan seni pertunjukan sulit bersaing. Disamping itu, lembaga pendidikan formal untuk kesenian belum cukup memadai. Di Indonesia, baru terdapat tiga lembaga pendidikan formal yaitu ISI, STSI, dan IKJ. Dalam rangka mendukung industri seni pertunjukan Indonesia sebagai negara yang kaya akan budaya, ISI mengadakan Indonesia Performing Art Mart (IPAM) setiap 2 tahun sekali.

Tabel 10 Kontribusi subsektor industri seni pertunjukan

\begin{tabular}{|c|c|c|}
\hline Indikator & Satuan & 2013 \\
\hline \multicolumn{3}{|c|}{ Berbasis Produk Domestik Bruto (PDB) } \\
\hline Nilai Tambah & Rp Milyar & 1147 \\
\hline$\%$ thd Ind. Kreatif & Persen & 0,74 \\
\hline$\Delta$ Nilai Tambah & Persen & 6,89 \\
\hline$\%$ thd Total PDB & Persen & 0,042 \\
\hline \multicolumn{3}{|c|}{ Berbasis Ketenagakerjaan } \\
\hline Jumlah TK & Orang & 79258 \\
\hline$\%$ thd Ind. Kreatif & Persen & 0,97 \\
\hline$\%$ thd Total TK & Persen & 0,07 \\
\hline$\Delta$ Jumlah TK & Persen & 1,44 \\
\hline Produktivitas TK & Rp Ribu & 14473 \\
\hline \multicolumn{3}{|l|}{ Berbasis Nilai Ekspor } \\
\hline Nilai Ekspor & Rp Juta & 259318 \\
\hline$\Delta$ Ekspor & Persen & 2,29 \\
\hline$\%$ thd Ind.Kreatif & Persen & 0,24 \\
\hline$\%$ thd Total Ekspor & Persen & 0,013 \\
\hline \multicolumn{3}{|c|}{ Berbasis Jumlah Usaha } \\
\hline Jumlah Usaha & Unit & 24236 \\
\hline$\Delta$ Jumlah Usaha & Persen & 3,18 \\
\hline$\%$ thd Ind.Kreatif & Persen & 1,00 \\
\hline$\%$ thd Total Usaha & Persen & 0,046 \\
\hline
\end{tabular}

Sumber: Kemenparekraf (2013) (diolah)

\section{Penerbitan dan Percetakan}

Lahirnya penulis-penulis baru yang menghasilkan karya fiksi dengan latar belakang budaya dan agama sesuai 
dengan konteks Indonesia, seperti El Shiraizy dengan Ayat-ayat Cinta dan Andrea Hirata dengan Laskar Pelangi juga merupakan peluang bagi industri penerbitan dan percetakan untuk terus tumbuh. Dalam konteks buku pelajaran, pemerintah telah mengadakan program pengalihan hak cipta dengan memberi insentif 100-175 juta bagi penulis yang karyanya lolos sebagai buku pelajaran.

Besarnya potensi pasar akan produk-produk percetakan seperti undangan, seminar kit, pamflet, poster, dan lain-lain mendorong industri ini untuk terus berkontribusi terhadap perekonomian. Industri penerbitan dan percetakan merupakan industri terpenting ke-3 dari 14 subsektor industri kreatif. Pada tahun 2013, industri ini mampu menyumbang PDB sebesar 19,7 triliun rupiah dan menyerap tenaga kerja sebanyak lebih dari 500 ribu orang seperti yang dapat dilihat pada Tabel 11 .

Tabel 11 Kontribusi subsektor industri penerbitan dan percetakan

\begin{tabular}{|c|c|c|}
\hline Indikator & Satuan & 2013 \\
\hline \multicolumn{3}{|c|}{ Berbasis Produk Domestik Bruto (PDB) } \\
\hline Nilai Tambah & Rp Milyar & 19733 \\
\hline$\%$ thd Ind. Kreatif & Persen & 12,8 \\
\hline$\Delta$ Nilai Tambah & Persen & 3,39 \\
\hline$\%$ thd Total PDB & Persen & 0,70 \\
\hline \multicolumn{3}{|c|}{ Berbasis Ketenagakerjaan } \\
\hline Jumlah TK & Orang & 505757 \\
\hline$\%$ thd Ind. Kreatif & Persen & 6,2 \\
\hline$\%$ thd Total TK & Persen & 0,5 \\
\hline$\Delta$ Jumlah TK & Persen & 0,36 \\
\hline Produktivitas TK & Rp Ribu & 39017 \\
\hline \multicolumn{3}{|l|}{ Berbasis Nilai Ekspor } \\
\hline Nilai Ekspor & Rp Milyar & 1755 \\
\hline$\Delta$ Ekspor & Persen & 0,32 \\
\hline$\%$ thd Ind.Kreatif & Persen & 1,64 \\
\hline$\%$ thd Total Ekspor & Persen & 0,08 \\
\hline
\end{tabular}

Berbasis Jumlah Usaha

\begin{tabular}{llr} 
Jumlah Usaha & Unit & 55396 \\
$\triangle$ Jumlah Usaha & Persen & 0,30 \\
\% thd Ind.Kreatif & Persen & 2,33 \\
\% thd Total Usaha & Persen & 0,10 \\
\hline
\end{tabular}

Sumber: Kemenparekraf (2013) (diolah)
Namun, masih ada kendala dalam industri penerbitan dan percetakan ini. Ketersediaan kertas sebagai bahan baku yang semakin sulit, dimana produksi dalam negeri sendiri hanya memenuhi sekitar 30 persen dari total kebutuhan kertas, sedangkan lainnya diperoleh dari impor.

\section{Layanan Komputer dan Piranti Lunak}

Subsektor industri kreatif ini memiliki potensi yang cukup besar untuk terus berkembang, yang ditandai dengan tingginya pertumbuhan mencapai lebih dari 8 persen per tahun pada tahun 2013 seperti yang dapat dilihat pada Tabel 12 .

Tabel 12 Kontribusi subsektor layanan komputer dan piranti lunak

\begin{tabular}{|c|c|c|}
\hline Indikator & Satuan & 2013 \\
\hline \multicolumn{3}{|c|}{ Berbasis Produk Domestik Bruto (PDB) } \\
\hline Nilai Tambah & Rp Milyar & 4275,5 \\
\hline$\%$ thd Ind. Kreatif & Persen & 2,8 \\
\hline$\Delta$ Nilai Tambah & Persen & 8,24 \\
\hline$\%$ thd Total PDB & Persen & 0,16 \\
\hline \multicolumn{3}{|c|}{ Berbasis Ketenagakerjaan } \\
\hline Jumlah TK & Orang & 69451 \\
\hline$\%$ thd Ind. Kreatif & Persen & 0,85 \\
\hline$\%$ thd Total TK & Persen & 0,06 \\
\hline$\Delta$ Jumlah TK & Persen & 0,60 \\
\hline Produktivitas TK & Rp Ribu & 61561 \\
\hline \multicolumn{3}{|l|}{ Berbasis Nilai Ekspor } \\
\hline Nilai Ekspor & Rp Milyar & 1125 \\
\hline$\Delta$ Ekspor & Persen & 1,60 \\
\hline$\%$ thd Ind.Kreatif & Persen & 1,05 \\
\hline$\%$ thd Total Ekspor & Persen & 0,054 \\
\hline \multicolumn{3}{|c|}{ Berbasis Jumlah Usaha } \\
\hline Jumlah Usaha & Unit & 8734 \\
\hline$\Delta$ Jumlah Usaha & Persen & 2,15 \\
\hline$\%$ thd Ind.Kreatif & Persen & 0,37 \\
\hline$\%$ thd Total Usaha & Persen & 0,02 \\
\hline
\end{tabular}

Sumber: Kemenparekraf (2013) (diolah)

Saat ini, industri layanan komputer dan piranti lunak menempati urutan ke-6 untuk kontribusi ekspor, urutan ke-8 untuk kontribusi PDB, dan urutan ke-9 untuk kontribusi jumlah 
usaha, sedangkan untuk kontribusi jumlah tenaga kerja, industri ini masih menempati urutan ke-7. Hal ini dikarenakan suplai tenaga kerja belum optimal.

Dalam rangka mendukung industri ini, pemerintah Indonesia membangun kawasan ekonomi khusus di Batam, Bintan, dan Karimun yang menarik minat investasi asing. Batam telah menjadi tempat investasi industri perangkat keras dunia dan terkoneksi dengan Singapura serta Malaysia. Berkembangnya kawasan-kawasan ini akan turut meningkatkan permintaan tenaga kerja lokal terampil di bidang perangkat lunak. Disamping itu, pemerintah juga telah mengeluarkan Undang-Undang No.35 Tahun 2007 berupa insentif pajak bagi BUMN agar menciptakan iklim riset dan pengembangan yang kondusif pada industri-industri besar BUMN yang akan menciptakan rantai suplai ke industri layanan komputer, perangkat lunak, dan perangkat keras.

\section{Radio dan Televisi}

Lulusan sarjana komunikasi setiap tahunnya mencapai ribuan. Jumlah ini merupakan suatu kekuatan tersendiri dalam pemenuhan kebutuhan tenaga kerja penyiaran. Industri ini juga didukung teknologi transmisi baru seperti mobile $T V$ yang semakin berkembang. Potensi subsektor industri ini ditunjukkan oleh pertumbuhannya di atas 6 persen pada tahun 2013 seperti yang terlihat pada Tabel 13 .

Industri radio dan televisi merupakan subsektor terpenting ke-5 dari 14 subsektor industri kreatif dalam hal kontribusi PDB, jumlah tenaga kerja, dan ekspor. Sementara itu, untuk kontribusi jumlah usaha, industri televisi dan radio masih menempati urutan ke-8. Untuk menaungi para pelaku industri ini, telah berdiri beberapa asosiasi, antara lain Asosiasi Televisi Lokal Indonesia, Asosiasi Televisi Swasta Nasional, Asosiasi Jurnalis Televisi, dan Asosiasi Radio.

Jumlah stasiun TV dan radio yang semakin banyak mencerminkan bahwa kesiapan infrastruktur penyiaran sudah memadai. Namun, televisi lokal di daerah sulit berkembang, padahal merupakan potensi untuk menggali budaya daerah. Apresiasi pasar terhadap hiburan seri dan film yang lebih tinggi dibandingkan informasi dan edukasi merupakan ancaman bagi televisi lokal.

Tabel 13 Kontribusi subsektor industri radio dan televisi

\begin{tabular}{|c|c|c|}
\hline Indikator & Satuan & 2013 \\
\hline \multicolumn{3}{|c|}{ Berbasis Produk Domestik Bruto (PDB) } \\
\hline Nilai Tambah & Rp Milyar & 7939 \\
\hline$\%$ thd Ind. Kreatif & Persen & 5,14 \\
\hline$\Delta$ Nilai Tambah & Persen & 6,82 \\
\hline$\%$ thd Total PDB & Persen & 0,29 \\
\hline \multicolumn{3}{|c|}{ Berbasis Ketenagakerjaan } \\
\hline Jumlah TK & Orang & 128061 \\
\hline$\%$ thd Ind. Kreatif & Persen & 1,57 \\
\hline$\%$ thd Total TK & Persen & 0,12 \\
\hline$\Delta$ Jumlah TK & Persen & 0,69 \\
\hline Produktivitas TK & Rp Ribu & 61997 \\
\hline \multicolumn{3}{|l|}{ Berbasis Nilai Ekspor } \\
\hline Nilai Ekspor & Rp Milyar & 1509 \\
\hline$\Delta$ Ekspor & Persen & 4,26 \\
\hline$\%$ thd Ind.Kreatif & Persen & 1,41 \\
\hline$\%$ thd Total Ekspor & Persen & 0,07 \\
\hline \multicolumn{3}{|c|}{ Berbasis Jumlah Usaha } \\
\hline Jumlah Usaha & Unit & 12481 \\
\hline$\Delta$ Jumlah Usaha & Persen & 0,51 \\
\hline$\%$ thd Ind.Kreatif & Persen & 0,52 \\
\hline$\%$ thd Total Usaha & Persen & 0,02 \\
\hline
\end{tabular}

\section{Riset dan Pengembangan}

Tingginya keanekaragaman hayati alam Indonesia tercatat nomor 3 di dunia setelah Brazil dan Zaire. Hal ini merupakan peluang bagi lahirnya penelitiandan pengembangan yang produktif. Industri ini didukung dengan adanya program Indigo (Indonesian 
Digital Community) oleh PT. Telkom, Indonesia Berprestasi Award oleh PT. Excelomindo Pratama dan Black Innovation Award oleh PT. Djarum. Hal ini diselenggarakan para pelaku industri riset dan pengembangan semakin termotivasi.

Tabel 14 menunjukkan bahwa pertumbuhan nilai tambah industri ini mencapai 7,44 persen pada tahun 2013 . Akan tetapi, kontribusinya belum signifikan. Pada tahun 2013, industri ini menyumbang 3,5 persen dari PDB industri kreatif atau menempati urutan ke-7 dari 14 subsektor industri kreatif. Sementara itu, untuk kontribusi ekspor menempati urutan ke-12 dan untuk kontribusi jumlah usaha dan jumlah tenaga kerja menempati urutan terakhir.

Tabel 14 Kontribusi subsektor industri riset dan pengembangan

\begin{tabular}{|c|c|c|}
\hline Indikator & Satuan & 2013 \\
\hline \multicolumn{3}{|c|}{ Berbasis Produk Domestik Bruto (PDB) } \\
\hline Nilai Tambah & Rp Milyar & 5387 \\
\hline$\%$ thd Ind. Kreatif & Persen & 3,5 \\
\hline$\Delta$ Nilai Tambah & Persen & 7,44 \\
\hline$\%$ thd Total PDB & Persen & 0,2 \\
\hline \multicolumn{3}{|c|}{ Berbasis Ketenagakerjaan } \\
\hline Jumlah TK & Orang & 15373 \\
\hline$\%$ thd Ind. Kreatif & Persen & 0,19 \\
\hline$\%$ thd Total TK & Persen & 0,014 \\
\hline$\Delta$ Jumlah TK & Persen & 1,48 \\
\hline Produktivitas TK & Rp Ribu & 350419 \\
\hline \multicolumn{3}{|c|}{ Berbasis Nilai Ekspor } \\
\hline Nilai Ekspor & Rp Juta & 74665 \\
\hline$\Delta$ Ekspor & Persen & 1,86 \\
\hline$\%$ thd Ind.Kreatif & Persen & 0,07 \\
\hline$\%$ thd Total Ekspor & Persen & 0,004 \\
\hline \multicolumn{3}{|c|}{ Berbasis Jumlah Usaha } \\
\hline Jumlah Usaha & Unit & 2130 \\
\hline$\Delta$ Jumlah Usaha & Persen & 2,98 \\
\hline$\%$ thd Ind.Kreatif & Persen & 0,09 \\
\hline$\%$ thd Total Usaha & Persen & 0,04 \\
\hline
\end{tabular}

Sumber: Kemenparekraf (2013) (diolah)

\begin{tabular}{llr}
\multicolumn{2}{c}{ Dalam rangka mendukung } \\
industri ini, pemerintah telah \\
menerbitkan PP No.35 tahun 2007
\end{tabular}

tentang penyisihan anggaran institusi untuk melakukan kegiatan riset dan pengembangan.

\section{Analisis Pertumbuhan TFP (Total Factor Productivity) Industri Kreatif}

- Uji Chow

Hasil dari Chow Test menunjukkan bahwa nilai probabilitas sebesar 0.0000 berbeda sangat nyata $(\mathrm{P}<0.01)$ maka $_{0}$ ditolak. Artinya, Fixed Effect digunakan.

- Uji Hausman

Hasil dari Hausman Test signifikan karena probabilitas dari Hausman sebesar 0.0016 berbeda sangat nyata $(\mathrm{P}<0.01)$, maka $\mathrm{H}_{0}$ ditolak. Artinya, Fixed Effect digunakan.

Berdasarkan hasil uji Chow dan uji Hausman, maka hasil estimasi yang digunakan adalah model fixed effect. Pada Tabel 15, dapat dilihat bahwa tenaga kerja (TK) berpengaruh nyata terhadap PDB industri kreatif karena nilai probabilitasnya kurang dari taraf nyata 10 persen. Sementara itu, jumlah usaha (K) tidak berpengaruh nyata karena nilai probabilitasnya sebesar lebih dari taraf nyata 10 persen.

Tabel 15 Hasil estimasi untuk menghitung $\triangle \mathrm{TFP}$

\begin{tabular}{lcc}
\hline \multicolumn{3}{l}{ Variabel dependen: LNPDB } \\
\hline Variabel & Koefisien & Prob. \\
\hline LNTK & 0.843565 & $0.0000^{*}$ \\
LNK & 0.009308 & 0.8427 \\
\hline R-squared & 0.994907 \\
Prob(F-statistic) & 0.000000 \\
\hline
\end{tabular}

Keterangan: * signifikan pada $\alpha=0.05$

Langkah selanjutnya yaitu menghitung pertumbuhan tiap variabel per tahun dan didapat $\triangle \mathrm{PDB} / \mathrm{PDB}$, $\Delta \mathrm{TK} / \mathrm{TK}$, dan $\Delta \mathrm{K} / \mathrm{K}$. Kemudian, masingmasing nilai tersebut (kecuali $\triangle \mathrm{PDB} / \mathrm{PDB})$ dikalikan dengan masingmasing koefisien variabel dari hasil estimasinya sehingga dapat diukur nilai TFP setiap tahunnya untuk setiap 
subsektor industri kreatif berdasarkan persamaan (8).

Dari hasil perhitungan, terdapat 4 subsektor industri kreatif yang memiliki tren pertumbuhan teknologi yang negatif, yaitu arsitektur, permainan interaktif, layanan komputer dan piranti lunak, serta riset dan pengembangan. Hal ini dikarenakan kurangnya dukungan pemerintah untuk industri tersebut dalam bidang pendanaan. Belum ada lembaga pembiayaan khusus yang mendukung industri tersebut karena kendala agunan untuk mendapatkan pendanaan dan dikhawatirkan waktu kembalinya cukup lama. Tren pertumbuhan TFP 14 subsektor industri kreatif dapat dilihat pada Tabel 16.

Tabel 16 Tren rata-rata $\triangle$ TFP 14 subsektor industri kreatif

\begin{tabular}{lr}
\hline \multicolumn{1}{c}{ Subsektor } & Tren $\triangle \mathrm{TFP}(\%)$ \\
\hline Periklanan & 0,031 \\
Arsitektur & $-0,018$ \\
Pasar barang seni & 0,063 \\
Kerajinan & 0,026 \\
Desain & 0,067 \\
Fesyen & 0,029 \\
Film, video \&fotografi & 0,028 \\
Permainan interaktif & $-0,024$ \\
Musik & 0,012 \\
Seni pertunjukan & 0,005 \\
Penerbitan \&Percetakan & 0,114 \\
Layanan Komputer \& & $-0,005$ \\
Piranti Lunak & \\
Radio dan Televisi & 0,038 \\
Riset dan pengembangan & $-0,050$ \\
\hline
\end{tabular}

\section{Hasil Estimasi Faktor-faktor yang Memengaruhi PDB Industri Kreatif Indonesia}

1. Pemilihan Model

a. Uji Chow

Hasil dari Chow Test menunjukkan bahwa nilai probabilitas sebesar 0,0000 berbeda sangat nyata $(\mathrm{P}<0,01)$ maka $\mathrm{H}_{0}$ ditolak. Artinya, Fixed Effect digunakan. b. Uji Hausman

Hasil dari Hausman Test tidak signifikan karena probability dari Hausman sebesar 1,0000 lebih dari taraf nyata 10 persen, maka $\mathrm{H}_{0}$ diterima. Artinya, Random Effect digunakan.

2. Uji Kriteria Statistik

a. Uji F

Berdasarkan Tabel 17, nilai probabilitas $\mathrm{F}$ statistik bernilai 0,0000 yang artinya setidaknya ada satu variabel eksogen yang berpengaruh signifikan terhadap PDB industri kreatif Indonesia.

b. Uji-t

Tabel 17 menunjukkan bahwa variabel eksogen yakni pendidikan, jumlah tenaga kerja, pertumbuhan TFP, dan dummy kebijakan pemerintah secara individu berpengaruh signifikan terhadap PDB industri kreatif Indonesia. Sementara itu, variabel jumlah usaha tidak berpengaruh.

c. $\quad \mathrm{Uji} R^{2}$

Pada Tabel 17, didapatkan nilai Rsquared sebesar 85,2 persen. Nilai ini menunjukkan bahwa 85,2 persen perubahan endogen dapat dijelaskan oleh faktor-faktor di dalam model, sedangkan sisanya yaitu sebesar 14,8 persen dijelaskan oleh faktor lain di luar model.

Tabel 17 Hasil analisis regresi model PDB industri kreatif

\begin{tabular}{lcl}
\hline \multicolumn{1}{c}{ Variabel } & Koefisien & \multicolumn{1}{c}{ Prob. } \\
\hline Konstanta & $-4,098822$ & 0,0627 \\
LNTK & 0,290981 & $0,0596^{*}$ \\
LNPD & 1,563281 & $0,0000^{* *}$ \\
TFP & $2,09 E-08$ & $0,0174 * *$ \\
LNK & 0,130598 & 0,2571 \\
DUMMY & 0,514356 & $0,0000^{* *}$ \\
\hline R-squared & \multicolumn{2}{c}{0,989636} \\
Prob(F-stat) & \multicolumn{2}{c}{0,000000} \\
\hline Keterangan: *signifikan pada $\alpha=0,1$ \\
& **signifikan pada $\alpha=0,05$
\end{tabular}




\section{Faktor-faktor yang Memengaruhi PDB Industri Kreatif Indonesia}

\section{- Jumlah Tenaga Kerja}

Dari hasil estimasi model, diketahui koefisien jumlah tenaga kerja (LNTK) sebesar 0,290981. Artinya, peningkatan tenaga kerja sebesar satu persen akan meningkatkan PDB industri kreatif sebesar 0,290981 persen, ceteris paribus. Ketersediaan tenaga kerja terbukti mendorong PDB industri kreatif karena SDM merupakan sumber daya utama pada industri kreatif.

\section{- Pendidikan}

$\begin{array}{lrr}\text { Pendidikan dianggap memiliki } & \text { meranan paling penting dalam }\end{array}$ menentukan kualitas manusia. Dalam kaitannya dengan perekonomian kreatif, semakin tinggi kualitas SDM maka semakin tinggi PDB industri kreatif karena sumber daya utama pada industri kreatif adalah SDM yang berkualitas.

Dalam upaya meningkatkan perekonomian bangsa, pihak pemerintah menggalakkan pengembangan industri kreatif melalui Sekolah Menengah Kejuruan (SMK). Dari 14 subsektor industri kreatif, sebanyak 12 bidang sudah dapat diajarkan secara khusus di seluruh SMK di Indonesia. Disamping itu, perguruan tinggi juga berperan dalam upaya memenuhi kebutuhan SDM di bidang industri kreatif terutama yang berbasis informasi dan teknologi (IT). Kreativitas dan teknologi merupakan suatu proses yang berdampingan, maka pelaku industri kreatif dituntut untuk mampu mengikuti perkembangan teknologi (Rianse 2013). Saat ini, sudah banyak Fakultas Industri Kreatif yang berdiri di Indonesia. Dalam proses pembelajarannya, Fakultas Industri Kreatif tidak hanya memberikan pelatihan individu, namun juga kemampuan bekerja sama dengan industri.
Dari hasil estimasi, diketahui bahwa variabel pendidikan yang diwakili oleh jumlah SMK dan perguruan tinggi (LNPD) memiliki koefisien sebesar 1,563281 , berpengaruh secara signifikan terhadap PDB industri kreatif Indonesia.

\section{- Pertumbuhan TFP}

Produktivitas input juga dapat dipengaruhi oleh faktor-faktor termasuk kemajuan teknologi (Case dan Fair 2007). Salah satu cara untuk mengukur pengaruh teknologi terhadap pertumbuhan ekonomi dapat dilihat dari peran TFP. TFP merupakan faktor lain yang mempengaruhi pertumbuhan ekonomi selain tenaga kerja dan modal.

Berdasarkan hasil analisis, diperoleh nilai koefisien pertumbuhan TFP positif sebesar 2,09E-08. Hal ini membuktikan bahwa TFP merupakan salah satu faktor PDB industri kreatif yang merupakan hasil dari kemajuan teknologi (technical progress) dari faktor-faktor produksi.

\section{- Jumlah Usaha Industri Kreatif}

Pada tahun 2013, sektor industri kreatif merupakan sektor ke-5 terbesar dari 10 sektor ekonomi nasional dalam jumlah usaha yang tercipta. Secara keseluruhan, jumlah usaha yang bergerak di 14 subsektor industri kreatif di Indonesia berjumlah 2380884 unit usaha atau sekitar 4,5 persen dari jumlah seluruh usaha di Indonesia.

Dari hasil estimasi, diketahui bahwa koefisien variabel jumlah usaha (LNK) sebesar 0,130598. Akan tetapi, variabel jumlah usaha tidak memiliki pengaruh yang signifikan terhadap PDB industri kreatif Indonesia. Meskipun jumlah usaha terus meningkat, namun pelaku usaha industri kreatif seringkali terkendala biaya dalam meningkatkan teknologi pada usahanya.

- Dummy Kebijakan Pembentukan Kemenparekraf

Indonesia melihat industri kreatif terus tumbuh setiap tahunnya dan 
menjadi salah satu sumber kekuatan baru di era globalisasi ini. Pada tahun 2009, Presiden membentuk Kementerian Pariwisata dan Ekonomi Kreatif.

\section{Variabel dummy (DUMMY)} dengan nilai 0 untuk periode sebelum pembentukan Kemenparekraf dan nilai 1 untuk periode setelah pembentukan Kemenparekraf, memiliki nilai koefisien sebesar 0,514356 yang artinya beda ratarata antara PDB industri kreatif sebelum dan sesudah pembentukan Kemenparekraf adalah sebesar 0,514356 milyar rupiah. Koefisien positif menandakan bahwa PDB industri kreatif setelah pembentukan Kemenparekraf lebih tinggi daripada sebelum pembentukan Kemenparekraf. Terbukti dengan dibentuknya kementerian pariwisata yang dikombinasikan dengan ekonomi kreatif, mampu mendorong pertumbuhan ekonomi.

\section{Uji Kausalitas Granger}

Pada tahun 2013, nilai ekspor ekonomi kreatif yang mencapai 107,1 triliun rupiah dapat mendorong PDB industri kreatif karena ekspor merupakan salah satu komponen PDB. Demikian pula halnya PDB industri kreatif yang mencapai 433 triliun rupiah pada tahun 2013 dapat meningkatkan ekspor karena kondisi perekonomian yang mapan akan menarik investor untuk menanamkan modal di bidang usaha industri kreatif yang berorientasi ekspor. Hasil pengujian granger causality dapat dilihat pada Tabel 18.

Tabel 18 Hasil uji kausalitas Granger

\begin{tabular}{lll}
\hline Null Hypothesis: & F-Stat. & Prob. \\
\hline Y2 does not & & \\
$\begin{array}{l}\text { Granger Cause Y1 } \\
\text { Y1 does not Granger }\end{array}$ & 7.51879 & 0.0031 \\
Cause Y2 & 9.54184 & 0.0010 \\
\hline
\end{tabular}

Pada Tabel 18, diketahui bahwa yang memiliki hubungan kausalitas adalah yang memiliki nilai probabilitas yang lebih kecil daripada alpha 0,05 sehingga suatu variabel akan mempengaruhi variabel lain. Dari pengujian Granger diatas, hubungan timbal balik atau kausalitas adalah sebagai berikut:

- Variabel Y1 (PDB industri kreatif) memengaruhi Y2 (ekspor industri kreatif);

- Variabel Y2 (ekspor industri kreatif) memengaruhi Y1 (PDB industri kreatif).

Dengan demikian, disimpulkan bahwa terjadi kausalitas dua arah antara variabel Y1 (PDB industri kreatif dan Y2 (ekspor industri kreatif). Hal tersebut dapat dijelaskan, ketika terjadi peningkatan ekspor industri kreatif, maka secara positif juga ikut meningkatkan PDB industri kreatif. PDB yang tinggi mengindikasikan situasi ekonomi di suatu negara berjalan baik sehingga kondisi tersebut menyebabkan investasi meningkat, kemudian produksi meningkat, maka ekspor pun meningkat.

\section{SIMPULAN DAN SARAN Simpulan}

Berdasarkan penelitian yang telah dilakukan mengenai analisis pertumbuhan ekonomi dan ekspor produk industri kreatif Indonesia dengan periode analisis dari tahun 2006 hingga 2013, maka diperoleh beberapa kesimpulan yaitu:

1. Subsektor industri kreatif dengan kontribusi paling tinggi yaitu fesyen dan kerajinan. Pada tahun 2013, subsektor industri fesyen menyumbang PDB sebesar 65,1 triliun rupiah $(42,2$ persen dari total PDB industri kreatif), menyerap tenaga kerja sebanyak 3,8 juta orang (47,2 persen dari total tenaga kerja 
industri kreatif), menyumbang ekspor sebesar 76,7 triliun (71,7 persen dari total ekspor industri kreatif), dan memiliki jumlah usaha sebanyak 1,1 juta unit $(46,5$ persen dari total jumlah usaha industri kreatif). Selanjutnya, subsektor industri kerajinan menyumbang PDB sebesar 25,4 triliun rupiah $(15,1$ persen), menyerap tenaga kerja sebanyak 3,1 juta orang (38,2 persen), menyumbang ekspor sebesar 21,7 triliun (20,3 persen), dan memiliki jumlah usaha sebanyak 1 juta unit (45,2 persen). Sementara itu, subsektor dengan kontribusi terendah yaitu pasar barang seni, periklanan, dan seni pertunjukan dengan kontribusi yang belum mencapai 1 persen.

2. Hasil perhitungan TFP menunjukkan bahwa terdapat 4 subsektor industri kreatif yang memiliki tren pertumbuhan teknologi yang negatif, yaitu arsitektur, permainan interaktif, layanan komputer dan piranti lunak, serta riset dan pengembangan.

3. Hasil regresi model PDB industri kreatif Indonesia menunjukkan bahwa pendidikan (jumlah SMK dan perguruan tinggi), jumlah tenaga kerja, pertumbuhan TFP, dan kebijakan pemerintah berpengaruh nyata secara positif terhadap PDB industri kreatif Indonesia, sedangkan jumlah usaha tidak berpengaruh nyata.

4. Hasil uji kausalitas Granger menunjukkan bahwa terdapat bahwa PDB industri kreatif dan ekspornya saling mempengaruhi. Hal ini dikarenakan ketika terjadi peningkatan ekspor industri kreatif, maka secara positif juga ikut meningkatkan PDB industri kreatif. PDB yang tinggi juga dapat meningkatkan ekspor karena kondisi perekonomian yang mapan akan menarik investor untuk menanamkan modal di bidang usaha industri kreatif yang berorientasi ekspor.

\section{Saran}

Dari hasil penelitian yang diperoleh, maka beberapa masukan yang dapat diberikan oleh penulis adalah sebagai berikut:

1. Melihat peran industi kreatif yang penting bagi perekonomian Indonesia, baik dalam kontribusi PDB, partisipasi tenaga kerja, nilai ekspor, dan jumlah usaha, maka industi kreatif Indonesia perlu terus didukung oleh pemerintah, terutama subsektor fesyen dan kerajinan yang kontribusinya sangat tinggi terhadap industri kreatif. Sementara itu, untuk subsektor dengan kontribusi yang masih rendah diperlukan perhatian lebih dari pemerintah.

2. Variabel pertumbuhan TFP berpengaruh nyata terhadap PDB industri kreatif Indonesia. Oleh karena itu, pemerintah sebaiknya menganggarkan dana untuk terus melakukan perbaikan teknologi dalam industri kreatif, terutama yang pertumbuhan teknologinya masih negatif yaitu arsitektur, permainan interaktif, layanan komputer dan piranti lunak, serta riset dan pengembangan.

3. Variabel jumlah usaha tidak berpengaruh nyata terhadap PDB industri kreatif Indonesia. Hal ini dikarenakan banyak usaha industri kreatif yang masih terbatas teknologi sehingga usahanya belum maksimal. Oleh karena itu, pemerintah sebaiknya mengadakan lembaga pembiayaan untuk industri kreatif.

4. Variabel pendidikan (jumlah SMK dan perguruan tinggi) berpengaruh nyata terhadap PDB industri kreatif Indonesia. Oleh karena itu, pemerintah sebaiknya terus 
mengembangkan sistem pendidikan di Indonesia yang mendorong masyarakat untuk bisa kreatif dan menjalin kerjasama dengan industri.

5. Diperlukan peran pemerintah untuk meningkatkan daya saing produk industri kreatif yang diperdagangkan untuk mengantisipasi persaingan sesama eksportir produk sejenis agar ekspor industri kreatif terus meningkat dan PDB industri kreatif juga meningkat.

\section{DAFTAR PUSTAKA}

Case, K. E., Fair R. C. 2007.Prinsipprinsip Ekonomi Jilid I. Edisi kedelapan. Erlangga. Jakarta.

Garnham, N. 2005. From Cultural to Creative Industries: An Analysis of The Implications of The 'Creative Industries' Approach to Arts and Media Policy Making in United Kingdom. International Journal of Culture Policy, Volume 11, No.1.

Gujarati, D. 2004. Basics Econometrics.Fourth Edition.The Megraw-Hill Companies. New York.

Kemendag. 2008. Pengembangan Ekonomi Kreatif Indonesia 2025. Kementerian Perdagangan. Jakarta.

Kemenparekraf. 2013. Data Statistik. Pusat Data dan Informasi. Kementerian Pariwisata dan Ekonomi dan Kreatif. Jakarta.

Khristianto, W. 2008.Peluang dan Tantangan Industri Kreatif di Indonesia. Jurnal Bisnis dan Manajemen, Volume 5, No.1: 3348.

Kuncoro, M. 2010. Visi Indonesia 2030: Quo Vadis? Universitas Gajah Mada. Yogyakarta.

Mahyuddin, Juanda, B., Siregar, H. 2006. Total Factor Productivity dan Dampaknya Terhadap

Kesempatan Kerja di Provinsi

Sulawesi Selatan. Jurnal Sosial

Ekonomi Pertanian No 23.

Mankiw, N.G.. 2007. Makroekonomi.

Edisi Keenam. Liza F, penerjemah; Hardani $\mathrm{W}$, editor. Jakarta: Erlangga. Terjemahan dari: Macroeconomics. Sixth Edition. Harper and Row Publisher. New York.

Maslow, A. 1984, Motivasi dan Kepribadian, Seri Manajemen No. 104. Cetakan Pertama. PT. Pustaka. Jakarta.

Mehrara, M., Firouzjaee B. A. 2011. Granger Causality between Export Growth and GDP Growth in Developing Countries. International Journal of Humanities and Social Science, Volume 1, No.16.

Mikić, H. 2012. Public policy and creative industries in Serbia. Dalam: 7th International Conference on Cultural Policy Research. Proceeding of a workshop held in Barcelona, Spain, 9-12 July 2012.

Rani, P. 2011. Impact of Technology on Creative Industries: A Study of The Indian Film Industry. Dalam: International Search Conference. Proceeding of a workshop held in Kuala Lumpur, Malaysia, 28-29 May 2011.

Rianse, U. 2013. Peran Pemerintah dan Perguruan Tinggi dalam Pengembangan Ekonomi Kreatif Berbasis Budaya Lokal. Dalam: Kongres Kebudayaan Indonesia (KKI) di Yogyakarta, Indonesia, 8-11 Oktober 2013.

Winarno, W. W. 2009. Analisis Ekonometrika dan Statistika dengan Menggunakan Eviews. STIM YKPN, Yogyakarta. 
Sebayang, L.R. 2012.Analisis Prospek Ekspor Industri Kreatif dalam Meningkatkan Perekonomian Indonesia. Tesis. Program Pascasarjana. Universitas Sumatera Utara, Medan.
Zhang, J., Kloudova, J. 2011. Factors which Influence the Growth of Creative Industries: Cross-section Analysis in China. Current Issues of Business and Law, Volume 3: 104-117. 